\title{
The Validation of the Korean Version of Pain Catastrophizing Scale in the Sports Context
}

\author{
Inchon Park* \\ Department of Sports Science, Seoul National Univeristy of Science and Technology, Seoul, Korea
}

\begin{abstract}
[Purpose] Recently, studies associated with the negative physical and mental effects of athletes' pain have received extensive attention. This study confirmed the validity of the pain catastrophizing scale (PCS) developed in clinical settings and is widely used in the sports field, and examined their relationship between the perceived stress levels and fear of pain. [Methods] The pain catastrophizing consisted of 13 items of three factors which are Helplessness (6 items), Rumination(4 items), Magnification(3 items). To verify the validity, PSC was revised by following the recommended revision guideline procedures. To test the validation of pain catastrophizing, 206 adult athletes were recruited including the collegiate, professional, and national levels. The participants were instructed to complete questionnaires to assess the level of pain catastrophizing, perceived stress, and fear of pain. Confirmatory factor analysis (CFA) to test the fit of measurement model was adopted to examine three higher-order three-factor measurement models. [Results] In results, confirmatory factor analysis indicated that the Korean version of the pain catastrophizing scale demonstrated a good model fit of measurement when removing one item with a significantly lower factor load as well as the reliability of the scale was reasonable. The pain catastrophizing had a meaningful positive direct relation with perceived stress level and fear of severe pain. In addition, construct validity and predictive validity of PCS showed valid. [Conclusions] Based on the results of this study, the Korean sports pain catastrophizing scale can be used to measure the subjective pain intensity of Korean athletes. In addition, it is expected to provide fundamental information for evaluating athletes' post-injury rehabilitation processes.
\end{abstract}

Key words: pain catastrophizing, fear of pain, perceived stress, validation, athletes

\section{서 론 \\ 강도 높은 신체적 노력을 쏟는 운동선수들은 극심한 통증 속에서도 고강도 훈련에 지속적으로 참가하고 있다 (Atkinson, 2008; Cook, O'connor, Eubanks, Smith, \& Lee, 1997). 이것은 운동선수들이 통증을 인식하는 방식}

논문 투고일 : 2021.05.10.

논문 수정일 : 2021.06.09.

게재 확정일 : 2021.06.30.

* 교신저자 : 박인천(pic2pac@gmail.com)
때문이기도 하다. 운동선수들의 통증 민감도 저하(pain hyposensitivity)는 타고난 특성이기도 하지만 환경의 영 향을 받기도 한다(Taylor \& Taylor, 1998). 이런 민감성은 운동선수들이 운동에 참여하고 지속하고자 하는 선택에 영 향을 주기도 하고 운동에 참여 하면서 이런 민감성의 저하가 나타나기도 한다(Assa, Geva, Zarkh, \& Defrin, 2019). 통증을 느끼는 역치는 개인에 따라 차이가 있긴 하나 선수와 비선수 사이에 큰 차이가 없는 것으로 밝혀졌으나, 통증을 견뎌 내는 내성은 운동선수가 월등이 높은 것으로 보고되어 (Tesarz, Schuster, Hartmann, Gerhardt, \& Eich, 
2012) 운동선수와 일반인의 통증 저항력에 대한 차이를 확 인했다. 또한 미식 축구 선수의 통증 내성이 달리기나 라켓 종목선수들의 내성 보다 높은 것으로 나타나 (Eitter, 1980; Ryan \& Kovacic, 1966) 통증 내성에 대한 효과는 스포츠 종목의 특성에 따라 달라질 수 있다고 언급하였다.

운동선수들의 통증 조절에 관한 연구는 국내뿐 아니라 해 외에서도 소수에 지나지 않는다. 운동선수들의 통증과 관련 된 국내연구들은 운동선수들이 느끼는 통증과 관련된 연구 는 근력(Wang, Ahn, \& Kim, 2016; Lee \& Kim, 2004), 근 활성도(Park, Kim, \& Noh, 2008), 관절 가동 범위(Jee, 2002)와 같은 생리학적 역학적 변인들에 집중되어왔다. 통 증 인식에 대한 해외 연구에서 수영, 싸이클, 달리기를 순차 적으로 진행해야 하는 지구력 경기인 철인 3종 경기에 참여 하는 선수들의 경우 비선수들보다 통증에 대해 민감하지 않 고 효과적인 통증 조절이 가능하다고 밝혀졌다 (Geva \& Defrin, 2013). 철인 3종 경기, 레슬링, 수영, 투기 종목 등 여러 유형의 참가자를 대상으로 한 연구에서도 비슷한 연구 결과를 보고했지만(Flood, Waddington, Thompson, \& Cathcart, 2017), 또 다른 연구에서는 지구력 경기 선수들 이 통증에 더 민감하다고 밝혀 정반대의 결과를 보고했다. 이와 같이 리뷰한 내용을 종합하면 운동선수의 통증 지각에 대한 일관된 결과는 아직 보고되지 않고 있다.

스포츠 분야에서 통증 인식에 대한 예측 요인을 연구하는 데 더 많은 관심을 기울여야 하는 이유는 첫째, 스포츠 활동 에서 통증에 대한 포괄적인 이론적 틀을 수립하기 위해서는 통증 경험에 영향을 미치는 심리적 요인에 대한 이해가 선행 되어야 한다. 특히 재활 현장에서 통증의 강도는 훈련의 계 속성을 유지하는 가장 강력한 예측 인자 중 하나이다 (Sullivan, Stanish, Waite, Sullivan, \& Tripp, 1998). 둘 째, 스포츠 손상 후 효과적인 통증 관리는 스포츠 참가자의 주관적인 통증 경험에 대한 명확한 이해에서 시작되어야 한 다(Taylor \& Taylor, 1998). 이러한 맥락에서 파국화 (catastrophizing)는 스포츠와 관련된 개인의 통증을 예측 하는 중요한 요인이 될 수 있다. 스포츠 참여를 통해 발생하 는 통증에 대한 반응을 평가하기 위해 고안된 척도의 요인 중 파국화는 중요한 요인으로 확인되었다(Meyers, Bourgeois, Stewart, \& LeUnes, 1992).

Sullivan et al.(1995)은 파국화는 개인이 통증 감각에 지나치게 집중하고, 통증에 주는 위협에 대한 정도를 과장 하여 통증을 주는 상황에 효과적으로 대처할 수 없다고 인식
하게 되는 과정이라 정의하였다. Sullivan et al.(1995)은 다양한 대상과 통증 상황에서 사용 될 수 있는 통증 파국화 척도(Pain Catastrophizing Scale: PCS)를 개발하였다. 요인 분석을 기반으로 한 선행연구에서 파국화는 반추 (reminiscent) “통증에 대한 생각을 떨쳐버릴 수 없다.”, 확 대(magnification) "뭔가 심각한 일이 벌어질 것 같아 걱정 된다.”, 무력화(helplessness) “통증을 줄일 수 있는 방법은 없다." 세 가지 요인으로 이루어진 통합된 개념으로 볼 수 있다고 제안했다. 나아가 임상현장에서 개발된 통증 파국화 척도를 스포츠현장으로 확대한 연구(Sullivan et al., 2000)에서도 동일한 개념이 확인되어 유럽, 아시아 등 여러 국가의 언어로 번안된 파국화 척도가 스포츠현장에서 사용 되고 있다(Olmedilla Zafra, Ortega Toro, \& Cano, 2013; Ximing Xu, Xianzhao Wei, Fei Wang, Jie Liu, \& Hui Chen, 2015). 통증 파국화 척도는 임상 현장 뿐 아 니라 스포츠 현장에서 통증 반응과 관련된 파국적 사고의 자 기보고식 측정 도구로 널리 이용되고 있다. 북미, 유럽에서 스포츠 통증 파국화는 많은 관심을 받고 있지만 국내 연구는 관심을 받지 못하고 있다. 결과적으로 국내 운동선수들 인 식하는 통증에 대한 통합된 개념을 측정할 수 있는 도구의 필요성이 대두되고 있다.

특히, 접촉종목 선수의 외상을 종목의 특성이 지닌 본질 에 기인한다는 단순한 접근방식과 달리 실제 외상 이전에 운 동선수들의 부상에 대한 주관적 반응을 이해하는 사전접근 방식은 이러한 위험요소로부터 벋어날 수 있는 기회를 향상 시킬 수 있다고 강조했다(Meyers, Bourgeois, \& LeUnes, 2001). Meyer et al.(2001)의 연구에서 접촉종목 선수의 통증 파국화 수준은 비접촉 종목 선수들에 비해 낮은 것으로 나타났으며 선수의 순위와 성별에 따라서도 파국화 수준의 차이가 발견됐다. 통증에 대해 과도하게 집착하게 되면 통 증을 유발하는 행위에 대한 두려움이 높아지게 되고 이는 통 증내성의 저하와 각성수준의 과도한 증가 및 여러 가지 심리 적 문제들을 야기한다(Cioffi, 1991). 반면, 통증에 대한 정 확한 자기인식은 통증이 일상생활, 훈련, 시합, 그리고 대인 관계를 방해하는 정도를 줄이는데 도움을 줄 수 있으며 결과 적으로 운동선수의 주관적 통증 정보를 기초로 한 대처전략 은 통증 속에서도 자신의 궁극적인 목표를 달성할 수 있도록 유도한다(Deroche et al, 2011; Cano, Mayo, \& Ventimiglia, 2006). 결국, 운동선수의 통증 파국화 수준 은 통증 두려움의 증가와 관련되어 부정적 심리상태를 유발 
하여 부상이나 손상과 같은 수행의 악영향을 미치게 된다.

통증 파국화 설문지는 만성 통증을 가진 환자들을 대상으 로 임상 및 실험 연구를 통해 개발되었고(Sullivan et al., 1995), 다양한 문화권과 연구 집단을 대상으로 활용되어 오 고 있지만 스포츠 상황에 맞는 척도로 활용되기에 고려되어 야 할 사항들이 확인되었다(Sullivan et al., 2000; Meyer, Sprott, \& Mannion., 2008). 먼저, 기존의 통증 파국화 척 도는 만성 통증 환자를 대상으로 임상 및 실험 절차를 거쳐 개발되었기 때문에 운동선수들이 거치는 인지과정과는 차 이가 발견된다는 것이다. 대표적으로 파국화 척도는 응답자 들에게 통증경험에 대한 자신의 기억에 의존하여 질문에 응 답하도록 요구되며 그 통증에 대한 인지적-심리적 반응이 다른 통증 상황에 일관적으로 연결된다는 가정으로부터 출 발하게 된다. 따라서 스포츠 상황에서 선수들이 지각하는 통증과는 차이를 보인다는 것이다(Olmedilla Zafra et al., 2013). 첫째, 임상 현장에서는 만성통증 환자들이 생활이나 병상에서 지각하는 위협적 통증에 대한 주관적 강도를 강조 한 반면, 스포츠에서 위협적 통증은 승패를 결정하는 수행 능력의 결정요소로 임상 현장과 큰 차이점이 있다. 둘째, 파 국화 척도의 타당화 과정을 위해 진행된 실험 연구에서 통증 유발을 위해 사용된 한냉혈압감시(cold pressor task)는 운 동선수들에게는 통증으로 인해 부상을 입을 수 있다는 자각 을 일으킨 다기 보다는 운동 후 염증이나 통증을 경감시키는 방법으로 사용되기 때문에 파국화의 확대 요인과 관련성을 찾기 힘들다는 제약이 있었다(Sullivan et al., 2000). 따라 서 모든 아이템을 더한 총점을 제시하는 기존 방식 보다는 특정 하위 변인의 점수를 제시하거나 총점을 제시해야 할 경 우 각 하위변인의 점수를 따로 제시 할 것을 제안하였으며, 구성 타당도의 확인을 위해 각 하위 변인과 관련된 통증 두 려움, 장애, 우울, 및 스트레스와 같은 변인과의 관계성을 다 중회귀분석으로 제시하는 것이 바람직하다고 제안하였다 (Meyer et al, 2008).

운동선수의 삶에서 통제할 수 없는 통증은 향후 더욱 심각 한 손상을 유발하거나 심리적 문제를 야기하는 부정적 영향 을 줄 수 있으며 결과적으로 선수들이 훈련이나 시합에서 오 는 중압감과 운동수행에 대한 부담의 상승작용으로 스트레스 수준은 더욱 높아 질 수밖에 없다(Putukian, 2016). 운동선 수에게 통증은 다른 집단의 성인들에 비해 운동수행에 직접 적 영향을 미치게 되어 주요 스트레스요인으로 작용한다 (Putukian, 2016). 적절히 관리되지 못한 통증으로 인한 생
리, 심리, 사회적 문제들의 시너지는 파국적 경험을 야기한다 (Bumann, Banzer, \& Fleckenstein, 2020). 이와 관련된 사전 연구에서 높은 수준의 자기 연민(self-compassion)이 나 회복 탄력성을 지닌 선수들은 통증이나 부상에 대처하는 능력이 뛰어나다는 결과를 보고하였다(Reis et al.,2015). 무엇보다 심리적 자원, 통증관리 기술, 효율적 대처전략은 통 증 치료 과정에서 필수적이라 할 수 있다.

통증 파국화의 반추, 확대, 무력감 요인은 스트레스 대처 에서 나타나는 1 차적, 2 차적 평가과정의 특성을 공유한다. 구체적으로 확대와 반추는 개인이 통증 자극의 위협 정도를 과장하고 집착하는 1 차적 평가과정과 관련되며, 무력화는 그 통증 자극을 감당해 낼 수 있는 능력이 없다고 부정적으로 판단하게 되는 2차적 평가과정과 관련된다(Sullivan et al, 1995). 따라서, 통증 관리를 위한 중재방안에서 반추와 무력 감을 기반으로 잠재적 목표를 제시할 수 있다. 반추적 인지 (ruminative cognition)에 대해서는 고통스러운 통증에 집 중되는 주의력을 전환 또는 분산 시키는 전략을 활용할 수 있 으며, 통증으로 인해 무력감을 느끼는 선수들에게는 부정적 사고를 긍정적인 사고로 바꾸는 훈련 목표로서 제공될 수 있 다. 반추와 무력감의 개선을 목표로 한 중재 방안은 통증 강 도를 최소화하는 것 뿐 아니라 재활과정에도 영향을 미칠 수 있다(Gilliam, Craner, Morrison, \& Sperry, 2017). 통증 강도가 활동을 유지하는데 중요한 결정인자라는 것을 감안 할 때, 통증을 최소화할 수 있는 능력을 가진 개인은 그 통증 을 유발하는 활동을 더 길게 지속할 수 있다.이러한 관점에 서 통증 파국화와 관련된 불안, 우울, 스트레스와 같은 부정 적 심리 변인들과의 연결성을 규명하는 과정이 강조되고 있 다(Meyer et al, 2008). 국내 스포츠 연구 분야에서는 혈중 젖산과 같은 생리학적 지표를 활용하여 통증과 스트레스의 관계를 연구하거나(Oh, 2020), 스트레스 요인과 대처 방안 의 탐색 과정에서 주요 요인으로 통증이 언급되는 식의 간접 적 확인 과정을 거쳐 왔다(Jang \& Kang, 2018; Jo, Lee \& $\mathrm{Kim}, 2015)$. 그러나 국내 운동선수들이 느끼는 주관적 통증 강도에 대해서는 거의 알려진 바가 없으며 운동선수의 통증 에 대한 생리심리사회적(biopsychsocial) 요인에 대한 직 접적이고 체계적 평가가 필요하다. 통증 파국화, 통증 두려 움 그리고 스트레스와의 관련성을 확인하게 된다면 운동선 수의 삶의 질과 정신건강에 대한 관심을 도모하고 스포츠종 목의 특성을 고려한 통증대처와 스트레스에 대한 차별화된 이해를 위해 제공할 수 있을 것으로 기대된다. 
따라서 이 연구에서는 Sullivan et al.(2000)이 개발한 통증파국화 척도가 국내선수들에게 활용 가능한 척도인지 확인하고 파국화와 스트레스 그리고 통증에 대한 두려움과 의 관계를 확인하였다. 이 연구는 국내 스포츠현장에서 관 심이 높아지고 있는 통증과 관련된 심리적 요인에 대한 이해 를 높이고 종목 특성 간 통증 인식에 대한 차이를 규명한다 는 점에서 연구의 의미가 있다.

\section{연구방법}

\section{1. 연구대상}

본 연구는 현재 운동선수로 활동 중 인 성인 엘리트 운동 선수(M=22.1세, $\mathrm{SD}=2.57$ 세) 206명을 대상으로 하였다. 이 중 남자선수는 125 명으로 $62.2 \%$ 를 차지하였으며 여자 선수는 76 명으로 $37.8 \%$ 를 차지 하였다. 조사대상의 선수급 과 접촉 스포츠 여부 등 일반적인 특징은 〈Table 1)과 같다. 접촉 스포츠와 비접촉스포츠는 사전 연구의 분류방식을 참 고하였다(Silva, 1983; Hwang, Choi, \& Kwon, 2019). 구체적으로 검도, 레슬링, 씨름, 축구, 핸드볼, 필드하키 등 을 접촉종목으로 분류하였으며 비접촉종목의 경우 선수 간 접촉이 없는 네트종목(테니스, 탁구, 배구)와 수영, 육상, 설 상, 표적 종목이 포함되었다. 설문지 회수 후 불성실한 응답 5 부를 제외한 201부를 최종 자료로 채택하고 분석하였다.

Table 1. Demographic information of the participants

\begin{tabular}{cccc}
\hline \hline \multirow{2}{*}{ Sex } & & frequency & $\%$ \\
& Male & 125 & 62.2 \\
& Female & 76 & 37.8 \\
\hline \multirow{2}{*}{ Sports } & Contact & 62 & 30.8 \\
Type & Non-contact & 139 & 69.2 \\
\hline \multirow{2}{*}{ Level } & Collegiate & 168 & 83.6 \\
& Professional & 26 & 12.9 \\
\hline \multirow{2}{*}{ Total } & National & 7 & 3.5 \\
\hline \hline
\end{tabular}

\section{2. 스포츠 통증 파국화 척도의 번안 과정}

한국형 스포츠 통증 파국화 척도의 번안 과정은 $\mathrm{Kim} \&$ Oh (2008)와 Beaton et al.(2000)이 제시한 자기보고식 검사지의 문화 간 적용과정 번안지침 6단계 가이드라인을 준수하면서 진행하였다. 첫 번째 단계는 '번역' 으로 척도의 내용을 이해하고 있는 스포츠심리학 박사 2인과 척도의 내 용에 대한 이해가 없는 이중언어자 1 인이 번역에 참여하였 다. 2단계는 '통합' 으로 두 가지 다른 번역본을 통합하여 차 이가 보이는 내용에 대한 합의를 도출했다. 3 단계는 '역번 역' 으로 측정결과에 대한 지식이 없는 영어를 모국어로 하 는 두 사람에게 한글로 번역된 척도를 영어로 역번역을 의뢰 했다. 이렇게 얻어진 모든 자료를 바탕으로 4단계에서 통계 전문가, 언어학전공자, 번역가로 구성된 전문가 회의를 거 쳐 내용에 대한 문맥의 정확성, 의미전달의 일치성, 문법을 만장일치에 도달한 사전 최종본을 생성했다. 5 단계는 '사전 검사' 단계로 3 요인 13 문항으로 구성된 척도를 운동선수 10 명을 대상으로 사전검사를 실시하였다. 예비조사 동안 각 문항에 대한 이해도를 점검하였으며 조사결과 문항의 이 해에 어려움이 없음을 확인하였다. 마지막 6단계는 '평가' 단계로 각 단계에서 보고서를 작성하여 연구책임자와 심사 위원의 평가를 받고 다음 단계 진행에 대한 승인을 득한 후 진행하는 방식으로 각 단계별로 보고서 작성과 평가가 이루 어졌으며 '평가' 단계는 1 단계부터 5단계까지 총 5회 이루 어졌다.

번안된 척도의 타당화 검증과정은 다음과 같이 이루어졌 다. 먼저, 척도에 대한 응답의 정규성과 신뢰도 분석 위해 기 술통계량과 신뢰도계수를 확인하였다. 둘째, 통증 파국화 척도 요인구조의 요인부하량과 적합도를 평가하기 위해 확 인적 요인분석을 실시하였다. 셋째, 통증 파국화의 각 하위 변인과 스트레스 수준, 그리고 통증 두려움 변인 간의 상관 관계분석을 통해 공인 타당도를 확인하였다. 넷째, 통증 파 국화 척도에 대한 집중타당도를 평가하여 척도의 개념다당 도를 검증하였다. 마지막으로, 파국화 척도의 하위요인과 스트레스 수준, 통증 두려움을 기준으로 다중회귀분석을 실 시하여 척도의 예측타당도를 검증하였다.

\section{3. 조사도구}

스포츠 통증 파국화 척도에 대한 준거 타당도(공인타당 
도 및 예측타당도)의 검증을 위해 지각된 스트레스와 통증 두려움 척도를 활용하여 통계적 검증 과정을 실시하였다.

\section{1) 지각된 스트레스}

설문에 참가한 운동선수들은 매번 훈련과 시합에서 느 끼는 신체적, 정신적 스트레스의 정도에 대해 응답하도록 했다. 훈련 또는 시합 시 느끼는 신체적, 정신적 스트레스에 대해 각각 따로 응답하도록 하였으며, 평가 척도는 "전혀 스 트레스 받지 않는다" (=0)에서 "상상 가능한 가장 극심한 스 트레스” (=10) 로 10점 척도로 응답하는 방식으로 스트레스 지수를 측정했다.

\section{2) 통증 파국화 질문지 (PCS)}

통증 파국화 척도는 (Sullivan, Bishop, \& Pivik, 1995) 는 13 문항으로 구성되었고 통증을 느낄 때의 사고와 감정 을 0 (전혀 그렇지 않다)에서 4 (항상 그렇다)까지의 5점 Likert 척도를 이용하여 파국적 사고의 정도를 평가하는 척 도이며, 무력감 (helplessness), 반추 (rumination), 확대 (magnification) 3개의 하위요인으로 구성되어 있다. 총점 의 범위는 0 점에서 52 점으로 점수가 높을수록 파국적 사 고 경향이 강한 것을 의미한다.

\section{3) 통증 두려움 질문지 (Fear of Pain)}

통증 두려움 질문지는 30 문항으로 구성되었고 다양한 통 증을 주는 상황을 묘사하고 있다 (McNeil \& Rainwater, 1998). 응답자는 각 상황에서 느끼는 통증을 1 에서 5 까지 5 점 Likert 척도를 이용하여 (점수 범위 30-150) 통증에 대 한 두려움을 평가하는 척도로 경미한, 심각한, 의료적 통증 의 3 가지 하위 요인으로 분류되어 점수가 높을수록 통증에 대한 두려움이 높은 것을 의미한다.

\section{4. 자료 분석}

본 연구에서수집된 모든 자료는 SPSS ver.20.0 프로그램 과 AMOS ver.26 프로그램을 사용하여 분석하였다. SPSS 프로그램은 기술통계량, 신뢰도 분석, 상관분석, 변량분석 을 위해 사용하였으며 AMOS 프로그램을 이용해 확인적 요 인분석을 실시하였다. 실시하였으며 또한 운동선수들이 느 끼는 스트레스 정도와 통증 지각의 상호 연관성과 영향관계 를 알아보기 위하여 통증 파국화와 통증 두려움 하부 항복
간의 상관관계 (correlation) 분석과 다중회기분석 (multiple regression)을 실시하였다. 본 연구의 모든 통계 적 유의 수준은 $\mathrm{p}=.05$ 로 하였다.

\section{연구결과}

\section{1) 기술 통계 및 신뢰도}

〈Table 2〉에 나타난 통증 파국화 문항에 대한 기술 통계 결과, 무력화 6문항에 대한 평균값은 1.99-3.17 ( $\mathrm{SD}=.80-1.19)$ 으로 나타났으며 반추 4문항에 대한 평균값 은 2.56-3.44(SD=1.03-1.15), 그리고 확대 3문항에 대한 평균은 2.59-2.97(SD=1.07-1.22)으로 분포하는 것으로 나타났다. 3요인 13 문항에 대한 스포츠 통증 파국화 척도의 왜도 및 첨도는 2 를 초과하는 문항이 없는 것으로 나타나 응 답자들에 대한 반응이 정규분포를 띄는 것으로 밝혀졌다.

스포츠 통증 파국화 척도의 신뢰도 검증은 Cronbach's $\alpha$ 계수를 통해 확인하였다. 분석 결과, 신뢰도 계수는 무력 화 $\alpha=.835$, 반추 $\alpha=.863$, 확대 $\alpha=.829$ 나타났으며 전체 문항의 신뢰도 값 또한 $\alpha=9.33$ 으로 나타나 높은 신뢰도 값 은 보이는 것으로 확인되었다. 일반적으로 내적 일관성은 8 이상의 수준이면 신뢰도가 높은 것으로 판단한다. 본 연구 에서 확인된 신뢰도 계수 값은 내적 일관성에서 요구되는 기 준에 부합되는 것으로 나타났다.

\section{2) 확인적 요인분석}

한국형 스포츠 통증 파국화 척도 요인구조의 요인부하량 과 적합도를 평가하기 위하여 확인적 요인분석을 수행하였 으며〈Fig. 1〉그 평가를 위해 절대 적합지수인 CMIN/DF, RMSEA 지수, 증분적합지수인 CFI, TLI지수, 그리고 간접 적합지수인 IFI 지수를 사용하였다.

스포츠 통증 파국화 척도 3 요인 13 문항에 대한 확인적 요인분석 결과, 절대적합지수, 증분적합지수 그리고 간접적 합지수 대부분이 적합도의 기준을 만족시키지 못하는 것으 로 나타났다〈Table 3〉. 따라서, 통증 파국화 척도를 스포츠 현장으로 확대하여 타당도를 검증한 Sullivan et al. (2000) 의 연구를 토대로 반추요인의 10 번, 11 번 문항과 무력화 요 인의 2 번, 3 번 문항의 측정오차 간 수정지수를 확인한 결과 각각 24.12 와 19.56 으로 나타나 오차항 간 공분산을 허용 
하여 연결하였다. 또한, 확인적 요인분석 결과 요인적재치 가 현저히 떨어지는 문항(12번)을 삭제하고 3요인 12문항 에 대한 확인적 요인분석을 다시 수행한 결과, 모형 적합도 의 기준에 충족되는 것으로 확인되었다.

구체적으로 NFI, CFI, 그리고 IFI 값은 .09이상일 경우 모델 적합도를 수용할 만한 기준으로 판단하며, .95 이상일 경우 적합도가 우수한 것으로 판단한다(Hu \& Bentler, 1998). RMSEA 지수는 .10 이하일 경우 양호한 적합도로 평가한다. 측정모형에 대한 적합도 지수는 3요인 12 문항의 통증 파국화 척도에서 $\mathrm{CMIN} / \mathrm{DF}(3.95), \mathrm{NFI}(.89)$, CFI(.91), 그리고 IFI(.91)으로 나타나 적합도 기준에 부합 하는 것으로 나타났다.

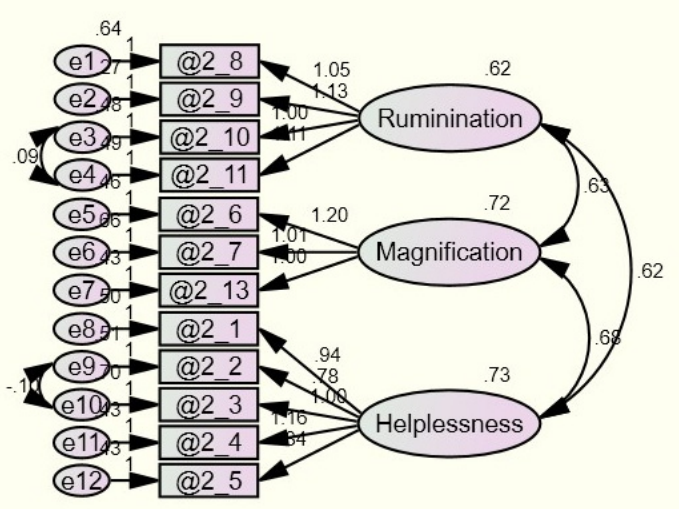

Fig. 1. Optimized baseline model for Athletes.

Table 2. Descriptive statistics for PSC items

\begin{tabular}{|c|c|c|c|c|c|c|}
\hline Higher Factor & Sub-factor & Items & M & SD & Skew & Kurt \\
\hline \multirow{13}{*}{$\begin{array}{c}\text { Pain } \\
\text { catastrophizing }\end{array}$} & \multirow{6}{*}{ Helplessness } & 1. I worry all the time about whether the pain will end. & 2.75 & 1.07 & -.19 & -.97 \\
\hline & & 2. I feel I can't go on. & 2.42 & .97 & .46 & -.18 \\
\hline & & 3. It's terrible and I think it's never going to get any better & 3.17 & 1.19 & -.28 & -.86 \\
\hline & & 4. It's awful and I fell that it overwhelms me. & 2.97 & 1.19 & -.09 & -1.02 \\
\hline & & 5. I feel I can't stand it anymore. & 2.31 & .97 & .53 & -.25 \\
\hline & & 12. There's nothing I can do to reduce the intensity of the pain.* & 1.99 & .80 & .61 & .38 \\
\hline & \multirow{4}{*}{ Rumination } & 8. I anxiously want the pain to go away. & 3.44 & 1.15 & -.47 & -.49 \\
\hline & & 9. I can't seem to keep it out of my mind. & 2.64 & 1.03 & .22 & -.69 \\
\hline & & 10. I keep thinking about how much it hurt. & 2.56 & 1.05 & .15 & -.73 \\
\hline & & 11. I keep thinking about how badly $U$ want the pain to stop. & 2.92 & 1.12 & -.07 & -.66 \\
\hline & \multirow{3}{*}{ Magnification } & 6. I become afraid that the pain will get worse. & 2.97 & 1.22 & .01 & -1.03 \\
\hline & & 7. I keep thinking of other painful events. & 2.59 & 1.18 & .355 & -.82 \\
\hline & & 13. I wonder whether something serious may happen. & 2.66 & 1.07 & .20 & -.44 \\
\hline
\end{tabular}

* deleted item in Korean version

Table 3. Measurement model fits for sport pain catastrophizing scale

\begin{tabular}{cccccccc}
\hline \hline & Measurement Model & CMIN/DF & NFI & CFI & IFI & RMSEA \\
\cline { 2 - 7 } & 3-factor 13items model & 4.16 & .86 & .89 & .89 & .10 \\
$\begin{array}{c}\text { Confirmatory } \\
\text { Factor } \\
\text { Analysis }\end{array}$ & 3-factor 12items model & 3.95 & .89 & .91 & .91 & .08 \\
\cline { 2 - 6 } & Original Scale & 1.15 & .89 & .97 & .97 &. \\
\cline { 2 - 7 } & Model Fit Indices & 5 under & .09 over & .09 over & .09 over & .10 under \\
\hline \hline
\end{tabular}




\section{3) 상관분석 및 공인타당도}

스포츠 통증 파국화 척도의 공인타당도를 확인하기 위해 인식된 스트레스 수준과 통증 두려움 변인 간의 상관분석을 수행하였다〈Table 4〉. 스포츠 통증 파국화 척도의 하위 요 인 중 반추는 지각된 신체적, 정신적 스트레스와 유의한 정 적상관을 보였고(r=.370-.404, ps〈.01), 확대, 무력화, 그 리고 심각한 통증과 정적상관을 나타냈다(r=.199-.789, $\mathrm{ps}$ 〈.01). 통증 파국화 하위요인 중 확대 또한 신체적 정신적 스트레스 및 무력화와 정적상관이 있는 것으로 나타났으며 $(\mathrm{r}=.354-.788, \mathrm{ps}<.01)$ 심각한 통증과 정적상관을 보였다 ( $\mathrm{r}=.195, \mathrm{p}<.01)$. 아울러 통증 파국화의 하위요인인 무력화 역시 스트레스와 심각한 통증에 유의한 정적상관계를 확인 했다(r=.192-.423, ps〈.01). 마지막으로 지각된 스트레스 는 통증 심각한 통증과 유의한 정적상관을 지닌 것으로 나타 났다(r=.157-.172, ps〈.05).

\section{4) 개념타당도}

스포츠 통증 파국화 척도 대한 개념타당도 검증을 위해 잠재요인과 측정변수 간의 일치성 정도를 평가하여 집중타 당도를 평가하였다(Table 5). 먼저 집중타당도 확인을 위해 주어진 공식을 통해 평균분산추출값과 잠재변인의 신뢰도 값을 도출하였다(Fornell \& Larcker, 1981). 집중타당도 평가를 위한 개념신되도는 기준값 .70 이상을 나타내면 집
중타당도가 양호하다고 평가되는 것으로(Anderson \& Gerbing, 1988) 무력화 .838, 반추 .843, 그리고 확대 .781로 나타나 기준값을 상회하는 것으로 확인되었다. 스포 츠 통증파국화 요인에 대한 평균분산추출값(AVE) 또한 무 력화 .510, 반추 .574 , 그리고 확대 .544로 나타나 기준값 .5 이상의 조건을 만족하는 것을 확인되었다.

\section{5) 예측타당도}

스포츠 통증파국화 척도의 예측타당도 검증을 위해 파국 화 척도의 하위요인을 종속변인으로 하고 지각된 스트레스 수준(신체적, 정신적)과 통증 두려움(극심한 통증)을 각각 독 립변인으로 설정하여 다중회귀분석 실시하였다〈Table 6〉.

통증 파국화에 미치는 신체적, 정신적 스트레스와 통증 두려움에 대한 회귀모형은 Durbin-Watson 값이 1.571.88 로 모두 2에 근접하여 적합하다고 판단하였다. 구체적 으로 신체적 스트레스는 무력화에 정적영향관계가 있는 것 으로 나타났다( $\beta=.333, \mathrm{t}=3.52, \mathrm{p}$ <.01). 반추는 신체적 스 트레스 $(\beta=.278, \mathrm{t}=2.92, \mathrm{p}<.01)$ 그리고 극심한 통증 $(\beta$ $=.130, \mathrm{t}=2.003, \mathrm{p}<.05)$ 과 정적인 영향 관계가 있는 것으 로 확인 되었다. 통증 파국화의 하위요인 확대 또한 신체적 스트레스 $(\beta=.232, \mathrm{t}=2.40, \mathrm{p}<.05)$ 그리고 극심한 통증 $(\beta$ $=.131, \mathrm{t}=1.98, \mathrm{p}<.05)$ 에 정적인 영향관계에 있는 것으로 나타났다. 상관분석 단계에서 상관관계가 확인된 정신적

Table 4. Mean, standard deviation, and summary of correlation analysis among study variables

\begin{tabular}{lcccccccccc}
\hline \hline \multicolumn{1}{c}{ Variables } & Mean & SD & 1 & 2 & 3 & 4 & 5 & 6 & 7 & 8 \\
\hline 1. Physical stress & 5.18 & 1.99 &. & & & & & & \\
2. Mental stress & 5.60 & 2.14 & $.738^{* *}$ &. & & & & & \\
3. Rumination & 2.72 & .86 & $.404^{* *}$ & $.370^{* *}$ &. & & & & \\
4. Magnification & 2.73 & 1.00 & $.371^{* *}$ & $.354^{* *}$ & $.789^{* *}$ &. & & & \\
5. Helplessness & 2.60 & .77 & $.423^{* *}$ & $.362^{* *}$ & $.686^{* *}$ & $.788^{* *}$ &. & & \\
6. Minor Pain & 2.99 & .91 & .081 & .004 & .066 & .057 & .075 &. & & \\
7. Severe Pain & 3.81 & .86 & $.157^{*}$ & $.172^{*}$ & $.199^{* *}$ & $.195^{*}$ & $.192^{* *}$ & $.655^{* *}$ &. & \\
8. Medical Pain & 2.94 & .89 & .001 & -.014 & .001 & .001 & .001 & $.796^{* *}$ & $.532^{* *}$ &. \\
\hline \hline
\end{tabular}

Note. ${ }^{* *} \mathrm{p}<.01,{ }^{*} \mathrm{p}<.05$ 
Table 5. Test of constructive validity of the measurement model of sports pain catastrophizing scale

\begin{tabular}{|c|c|c|c|c|}
\hline Factor Items & SRW & SE & C.R & AVE \\
\hline Helplessness 1 & .747 & .506 & \multirow{5}{*}{.838} & \multirow{5}{*}{.510} \\
\hline Helplessness2 & .671 & .522 & & \\
\hline Helplessness3 & .700 & .729 & & \\
\hline Helplessness4 & .829 & .442 & & \\
\hline Helplessness 5 & .740 & .430 & & \\
\hline Rumination8 & .717 & .642 & \multirow{4}{*}{.843} & \multirow{4}{*}{.574} \\
\hline Rumination9 & .862 & .275 & & \\
\hline Rumination 10 & .766 & .475 & & \\
\hline Rumination11 & .795 & .485 & & \\
\hline Magnification6 & .832 & .457 & \multirow{3}{*}{.781} & \multirow{3}{*}{.544} \\
\hline Magnification7 & .725 & .663 & & \\
\hline Magnification 13 & .789 & .434 & & \\
\hline
\end{tabular}

Table 6. Test of multiple regression analysis on the sports pain catastrophizing, perceived stress, and fear of pain

\begin{tabular}{|c|c|c|c|c|c|c|c|}
\hline Independent $\mathrm{V}$. & Dependent V. & $\mathrm{B}$ & $\mathrm{SE}$ & Beta & $\mathrm{t}$ & $\mathrm{R} 2$ & F-value \\
\hline \multirow{3}{*}{ Helplessness } & Physical Stress & .129 & .037 & .333 & $3.523 * *$ & \multirow{3}{*}{.199} & \multirow{3}{*}{$16.31^{* * *}$} \\
\hline & Mental Stress & .034 & .034 & .095 & 1.004 & & \\
\hline & Severe pain & .111 & .058 & .123 & 1.904 & & \\
\hline \multicolumn{8}{|c|}{ Durbin-Watson=1.888 } \\
\hline Independent V. & Dependent V. & $\mathrm{B}$ & $\mathrm{SE}$ & Beta & $\mathrm{t}$ & $\mathrm{R} 2$ & F-value \\
\hline \multirow{3}{*}{ Rumination } & Physical Stress & .121 & .041 & .278 & $2.925^{* *}$ & \multirow{3}{*}{.191} & \multirow{3}{*}{$15.491 * * *$} \\
\hline & Mental Stress & .058 & .038 & .143 & 1.497 & & \\
\hline & Severe pain & .131 & .065 & .130 & $2.003^{*}$ & & \\
\hline \multicolumn{8}{|c|}{ Durbin-Watson=1.874 } \\
\hline Independent V. & Dependent V. & $\mathrm{B}$ & $\mathrm{SE}$ & Beta & $\mathrm{t}$ & $\mathrm{R} 2$ & F-value \\
\hline \multirow{4}{*}{ Magnification } & Physical Stress & .117 & .049 & .232 & $2.408^{*}$ & \multirow{3}{*}{.168} & \multirow{3}{*}{$13.274 * * *$} \\
\hline & Mental Stress & .075 & .045 & .160 & 1.658 & & \\
\hline & Severe pain & .152 & .077 & .131 & $1.980^{*}$ & & \\
\hline & \multicolumn{7}{|c|}{ Durbin-Watson=1.571 } \\
\hline
\end{tabular}

스트레스는 회귀분석에서 통증 파국화 하위요인 간의 유의 한 영향관계를 보이지 않았다. 이러한 결과를 기초로 신체 적인 스트레스나 극심한 통증으로 인해 파국으로 치닫는 통 증 경험을 하게 된다는 가설을 뒷받침하며, 스포츠 통증 파 국화 척도로서 예측성을 확인하였다.
6) 종목 특성 별 인지된 스트레스, 통증 파국화 및 통증 두려움

종목 특성 별 인지된 스트레스, 통증 파국화, 통증 두려움 에 대한 차이를 알아보기 위한 평균과 표준 편차는 〈Table 7>에 제시되었으며, 본 연구의 결과에서 확인된 각 변인 간 
의 상관관계로 인해 종목 특성별 차이 검증을 위해 다변량분 석(MANOVA)을 진행하였으며 결과는 〈Figure 2〉와 같다. 구체적으로 접촉 종목 선수들은 경미한 통증을 지각하는 민 감도가 비접촉 선수들보다 유의하게 낮은 것으로 나타났으 며 $\mathrm{F}(1,199)=4.29, \mathrm{p}<.05,=.021$, 의료적 통증 역시 접촉
종목 선수들이 비접촉선수들 보다 유의하게 낮은 수준으로 인식하는 것으로 나타났다. $F(1,199)=7.94, p<.01$, =.038. 반면, 훈련이나 시합으로 인한 지각된 스트레스나 통증 파국화에서는 두 집단 간 유의한 차이를 발견하지 못하 였다(ps=.17-.64).

Table 7. Mean and standard deviation of perceived stress level, pain catastrophizing and fear of pain for contact and non-contact athletes

\begin{tabular}{|c|c|c|c|c|c|c|c|c|c|}
\hline $\begin{array}{l}\text { Sports } \\
\text { type }\end{array}$ & & Jariables & $\mathrm{M}$ & $\mathrm{SD}$ & $\begin{array}{l}\text { Sports } \\
\text { type }\end{array}$ & & ables & M & $\mathrm{SD}$ \\
\hline \multirow{8}{*}{ Contact } & \multirow{2}{*}{ stress } & Physical & 5.33 & 2.11 & \multirow{8}{*}{$\begin{array}{c}\text { Non } \\
\text { contact }\end{array}$} & \multirow{2}{*}{ stress } & Physical & 5.11 & 1.93 \\
\hline & & Mental & 5.46 & 2.20 & & & Mental & 5.66 & 2.12 \\
\hline & \multirow{3}{*}{$\begin{array}{c}\text { Pain } \\
\text { catastro } \\
\text { phizing }\end{array}$} & Helplessness & 2.56 & .78 & & \multirow{3}{*}{$\begin{array}{c}\text { Pain } \\
\text { catastrop } \\
\text { hizing }\end{array}$} & Helplessness & 2.61 & .76 \\
\hline & & Rumination & 2.65 & .87 & & & Rumination & 2.75 & .86 \\
\hline & & Magnification & 2.65 & 1.04 & & & Magnification & 2.77 & .98 \\
\hline & \multirow{3}{*}{$\begin{array}{l}\text { Fear } \\
\text { of } \\
\text { Pain }\end{array}$} & Minor & 2.79 & .89 & & \multirow{3}{*}{$\begin{array}{c}\text { Fear } \\
\text { of } \\
\text { Pain }\end{array}$} & Minor & 3.08 & .91 \\
\hline & & Major & 3.68 & .85 & & & Major & 3.86 & .86 \\
\hline & & Medical & 2.68 & .88 & & & Medical & 3.06 & .87 \\
\hline
\end{tabular}

\section{논 의}

통증과 관련된 파국적 사고는 통증을 증가시키는 원인이 될 수 있으며 특히 운동선수들에게 이런 파국적 사고는 훈련 이나 시합에서 자주 노출되는 극단적인 자극과 반응하여 더 심한 통증을 경험하게 되어 운동수행에도 악영향을 미치게 된다(Pen \& Fisher, 1994; Udry, Gould, Bridges, \& Beck, 1997). 파국화의 구성요소는 감정적 평가 상황으로 설명될 수 있다. 확대와 반추는 개인이 통증 자극의 위협 정 도에 집중하고 그 크기를 과장 시키는 1 차적 감정 처리과정 에 관련 깊고 무력감 요인은 개인이 통증에 효과적으로 대처 할 수 있는 능력을 부정적으로 판단하는 2차적 감정처리 과 정에 관련된다. 따라서, 통증 관리를 위한 중재방안에서 반 추와 무력감을 기반으로 잠재적 목표를 제시할 수 있다. 반 추적 인지(ruminative cognition)에 대해서는 통증에 집중 되는 주의력을 전환 또는 분산 시키는 전략을 활용할 수 있으 며, 통증으로 인해 무력감을 느끼는 선수들에게는 부정적 사 고를 긍정적인 사고로 바꾸는 훈련 목표로서 제공될 수 있 다. 반추와 무력감의 개선을 목표로 한 중재 방안은 통증 강 도를 최소화하는 것 뿐 아니라 재활과정에도 영향을 미칠 수

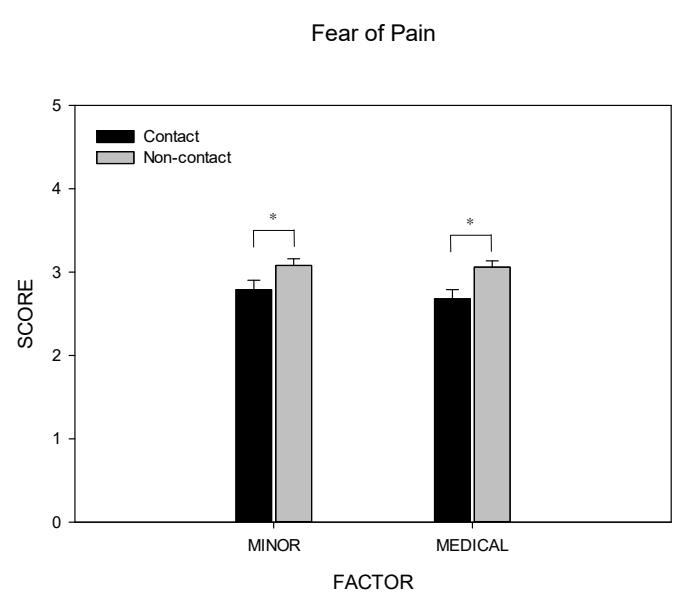

Fig. 2. Fear of pain score for contact and non-contact athletes as a function of fear of pain sub-factors. Error bars represent standard errors.

있다(Gilliam et al, 2017). 통증 강도가 활동을 유지하는데 중요한 결정인자라는 것을 감안할 때, 통증을 최소화할 수 있는 능력을 가진 개인은 그 통증을 유발하는 활동을 더 길게 지속할 수 있다.

스포츠 상황에서 선수들이 느끼는 주관적 통증 강도에 대 
한 이해를 높이고, 이를 구체적으로 측정하기 위한 통증 파 국화 척도가 북미, 유럽에서 널리 활용 됨에 따라 국내 선수 들을 대상으로 해당 척도를 적용하여 원 척도와의 구조 및 속 성을 확인하였다. 각 문항에 대한 반응을 원 척도와 비교하 였을 때, 본 연구에서 나타난 국내 선수들의 통증 파국화 수 준은 2.7(Median) 정도로 외상 이력이 없는 서양 선수들의 파국화 수준 (Median:1)보다 다소 높은 것으로 나타났으며 외상을 입었던 경험이 있는 선수(Median:5)나 현재 외상을 가진 서양 선수(Median:9)들 보다는 낮은 수준을 보였다 (Sciascia, Waldecker, \& Jacobs, 2020). 본 연구에서 통 증 관련 약물을 복용하지 않는 외상이 없는 운동선수들을 대 상으로 한 것을 감안했을 때 국내 선수들이 해외 선수들에 비 해 주관적으로 느끼는 통증의 강도가 높은 것을 의미한다. 이러한 결과는 해외 선수들에 비해서 국내선수들이 통증을 안고도 훈련이나 경기에 임하고 있다는 것으로 판단 할 수 있 으며 통증으로 인해 나타나는 신체적 심리적 부작용에 대한 이해와 효율적 통증 관리에 대한 필요성이 확인되는 결과이 다. 아울러, 원 척도와 한국형 척도의 신뢰도 값 비교에서도 원 척도는 전체=.84, 반추=.89, 확대=.65, 그리고 무력화 $=.84$ 로 나타났으며 본 연구에서는 전체=.93, 반추=.86, 확 대=.83, 그리고 무력화=.83으로 나타나 높은 내적 일관성이 확인되었으며, 통증 파국화 척도는 국내 선수들에게도 문항 에 대한 신뢰도가 우수하다는 것이 확인되었다.

Sullivan et al.(2000)의 연구에서 측정모델에 대한 적합 도 지수를 평가하기 위해 NFI, CFI, 그리고 IFI지수를 사용 하였다. 본 연구에서도 이 지수들을 기반으로 측정모델의 적 합도를 평가하였다. 원 척도와 본 연구의 적합도를 비교한 결과, 본 연구의 적합도 지수값이 원 척도와 유사한 값을 나 타내어 스포츠 통증 파국화 척도가 국내 선수들을 대상으로 했을 때도 동일한 요인 속성을 지니는 것으로 확인되었다. 최근 연구에서 모델의 복잡성을 알아보기 위한 기준으로 RMSEA 값을 사용하여 .05-.08 사이의 값을 지닐 때 분석된 자료의 수렴 적합을 판단하며, 대체로 .08-.10 범위에 속할 때 양호한 적합도로 판단한다(Marsh, Hau, \& Wen, 2004). RMSEA 지수와 함께 모델의 적합도 평가에서 보다 구체적인 진단 정보를 제공하는 CFI 값과 매개변수의 수에 영향을 받지않는 증분적합지수인 NFI지수는 0.9-0.95 사이 의 값을 가질 때 양호한 것으로 판단하며, 끝으로 IFI 지수는 실제 모델에 대한 자유도와 동일한 카이제곱을 가지는 지수 로 0.9 이상의 값을 지닐 때 이상적인 모델로 평가한다
(Widaman \& Thompson, 2003). 종합적으로 여러 적합 도 지수들에 대한 이론적 근거와 기준에 따라 본 연구에서 확 인된 스포츠 통증 파국화 척도에 대한 적합도 지수는 타당한 것으로 확인되었다. Sullivan et al.(2000)의 연구에서는 좌 식생활자와 운동선수를 대상으로 연구를 진행하여 각 대상 그룹의 적합도 지수를 제시하고 비교하였으나, 본 연구에서 는 운동선수만을 대상으로 하였고 접촉종목과 비접촉종목으 로 종목 특성을 구분하긴 하였으나 측정모델의 적합도 검증 에서는 샘플 수의 제약으로 인하여 종목에 대한 구분을 고려 하지 않고 결과값을 제시하였다. 따라서 후속 연구에서는 충 분한 대상자를 기반으로 종목별 특성을 고려하여 연구를 진 행한다면 척도의 교차 타당성을 검증할 수 있을 것이다.

원 척도 개발 당시 공인타당도의 확인을 위해 한냉혈압감 시(cold pressor-test)를 통해 통증 인식과 통증 파국화 요 인들과의 상관관계를 확인한 반면, 본 연구에서는 인식된 스 트레스 수준과 통증 두려움의 하위요인과의 상관관계를 통 해 공인타당도를 검증하였다. Sulllivan et al.(2000)은 사 전 연구에서 확인된 운동선수들이 인지하는 통증의 강도는 일반인과 다르다는 사실에 주목하여 스포츠 통증 파국화 척 도에 대한 타당성 연구를 진행하였다. 그 결과, 일반인과 운 동선수 모두에게 통증 파국화는 통증을 매개하는 중요한 예 측인자 임을 확인하였다. 운동선수들을 대상으로 한냉혈압 감시를 통해 발생된 통증 점수는 무력화 그리고 반추 요인에 서 유의한 상관관계가 확인되었다. 본 연구에서는 통증 점수 와 밀접한 관련이 있는 인식된 스트레스 수준과 통증 두려움 변인(Assa et al, 2019)과관련성을통해서공인타당도를검증 하였다. 본 연구에서 통증파국화의 각 요인은 신체적 스트레 스를 잘 예측하고 특히 반추와 확대요인은 극심한 통증에 대 한 두려움을 잘 설명하는 것으로 확인되었다. 통증 파국화와 통증과민증의 관계를 연구한 사전 연구에서 통증으로 인한 불안과 두려움은 파국화의 수준을 높이는 것으로 확인되어 (McHugh, Kneeland, Edwards, Jamison, \& Weiss, 2020) 보 연구의 결과와 같은 맥락으로 해석될 수 있다.

마지막으로 본 연구에서 종목 특성 간 인식된 통증 두려움 은 경미한 통증과 의료적 통증에서 비접촉 종목 선수들이 더 민감하게 반응하는 것으로 나타났다. 이러한 결과는 스포츠 종목의 특성을 지구력 종목과 근력종목으로 구분한 연구에서 도 확인되었다(Assa et al., 2019). 사전 연구에서도 운동선 수는 일반인 보다 낮은 통증 지각을 나타냈고 특히 지구력 종 목 선수들이 열통각역치검사에서 근력종목선수들보다 민감 
한 반면 통증에 대한 내성은 지구력 종목 선수들이 더 높은 것 으로 보고되었다. 이러한 결과는 통증이 순수한 감각이 아니 라 감각(sensation)에 감정(emotion)과 지각(perception) 이 더해진 경험이라는 것을 의미하며 운동 종목의 특성에 따라 통증을 관리하는 방법 또한 다르게 접근해야 함을 시사한다.

\section{결론 및 제언}

본 연구에서는 Sullivan et al.(2000)이 개발한 스포츠 통증 파국화 척도가 국내 운동선수들에게 사용 될 수 있도록 통계적 검증 절차를 거치고 인지된 스트레스와 통증 두려움 과의 관계를 규명하였다. 구체적으로 척도의 타당성을 검증 한 결과, 국내 운동선수에게는 3 요인 12 문항이 적합한 것으 로 나타났다. 스포츠 통증 파국화 척도의 각 하위요인들은 인식된 스트레스 수준 및 통증 두려움과 정적 상관을 보였 다. 통증 파국화의 무력화 요인은 신체적 스트레스를 정적 으로 예측하고 있으며, 확대와 반추 요인은 신체적 스트레 스와 극심한 통증에 대한 두려움을 정적으로 예측하는 것으 로 나타났다. 마지막으로 인식된 스트레스 수준과 통증 파 국화는 운동 종목의 특성에 따른 차이가 없는 것으로 나타났 으며 통증 두려움의 경우, 접촉 종목 선수들에 비해서 비접 촉 종목 선수들이 경미한 통증이나 의료적 통증에 더 민감한 것으로 나타났다.

임상현장에서 개발되어 스포츠 현장에서도 적용되고 있 는 통증파국화 척도는 국내 선수들에게도 타당하게 적용될 수 있음을 확인하였다. 향후 개선된 연구를 위해 다음과 같 은 사항이 고려되어야 한다. 첫째, 다양한 종목의 선수들을 대상으로 종목의 특성(접촉, 비접촉, 근력, 지구력, 팀, 개인 등)을 고려하여 스포츠 통증 파국화척도의 타당성을 검증할 필요가 있다. 둘째, 통증 파국화 척도는 무력감, 반추, 확대 와 같은 심리적 변인을 포함하고 있기 때문에 동기, 불안, 또 는 긍정성과 낙관성 요인이 포함된 회복탄력성 등과 같은 심 리적 변인 과의 관계 및 상호작용효과를 검증하는 연구 절차 가 필요하다. 셋째, 중재 프로그램에서 통증으로 인한 무력 감이나 확대를 통해 악화되는 것을 방지하기 위한 방안으로 통증 파국화의 하위요인을 타겟으로 한 중재 프로그램의 개 발과 효과 검증이 필요하다. 스포츠 통증 파국화 척도는 운 동선수들이 경험하는 통증에 대한 주관적 강도를 구체적으 로 측정하는데 유용한 도구이다. 앞으로 이 척도를 사용하
여 통증에 시달리는 선수나 손상 이후 재활을 통해 스포츠 현장으로 빠른 복귀를 준비하고 있는 선수들에게 자신이 느 끼고 경험하는 통증에 대한 정확한 정보를 제공할 수 있을 것으로 기대된다. 나아가 통증 재활 중재 프로그램에 사용 하여 효과성 검증에 대한 정량적 정보를 제공하고 통증으로 인한 무력감이나 부정적 상황을 확대하는 것을 방지하여 현 장으로 복귀를 촉진하는데 활용될 수 있기를 바란다.

\section{참고문헌}

Anderson, J. C., \& Gerbing, D. W. (1988). Structural equation modeling in practice: A review and recommended two-step approach. Psychological bulletin, 103(3), 411.

Anshel, M. H., \& Russell, K. G. (1994). Effect of aerobic and strength training on pain tolerance, pain appraisal and mood of unfit males as a function of pain location. Journal of sports sciences, 12(6), 535-547.

Assa, T., Geva, N., Zarkh, Y., \& Defrin, R. (2019). The type of sport matters: Pain perception of endurance athletes versus strength athletes. European Journal of Pain, 23(4), 686-696.

Atkinson, M. (2008). Triathlon, suffering and exciting significance. Leisure studies, 27(2), 165-180.

Beaton, D. E., Bombardier, C., Guillemin, F., \& Ferraz, M. B. (2000). Guidelines for the process of cross-cultural adaptation of self-report measures. Spine, 25(24), 3186-3191.

Bumann, A., Banzer, W., \& Fleckenstein, J. (2020). Prevalence of Biopsychosocial Factors of Pain in 865 Sports Students of the Dach (Germany, Austria, Switzerland) Region - A Cross-Sectional Survey. Journal of sports science \& medicine, 19(2), 323.

Cano, A., Mayo, A., \& Ventimiglia, M. (2006). Coping, pain severity, interference, and disability: the potential mediating and moderating roles of race and education. The Journal of Pain, 7(7), 459-468.

Cho, Lee, \& Kim. (2015). The Relationship among Anxiety, Self-efficacy, Coping with Stress, and Rehabilitation Adherence in Injured Athletes Who Participate in Sport Injury Rehabilitation Program. Journal of Sport and Leisure Studies. 60, 565-581.

Cioffi, D. (1991). Beyond attentional strategies: A 
cognitive-perceptual model of somatic interpretation. Psychological bulletin, 109(1), 25.

Cook, D. B., O'connor, P. J., Eubanks, S. A., Smith, J. C., \& Lee, M. (1997). Naturally occurring muscle pain during exercise: assessment and experimental evidence. Medicine and science in sports and exercise, 29(8), 999-1012.

Deroche, T., Woodman, T., Stephan, Y., Brewer, B. W., \& Le Scanff, C. (2011). Athletes' inclination to play through pain: a coping perspective. Anxiety, Stress \& Coping, 24(5), 579-587.

Eitter, T. J. (1980). Pain tolerance training applied to the athletic environment. Dissertation Abstract International, 41, 2005-2006.

Flood, A., Waddington, G., Thompson, K., \& Cathcart, S. (2017). Increased conditioned pain modulation in athletes. Journal of sports sciences, 35(11), 1066-1072.

Fornell, C., \& Larcker, D. F. (1981). Evaluating structural equation models with unobservable variables and measurement error. Journal of marketing research, 18(1), 39-50.

Geva, N., \& Defrin, R. (2013). Enhanced pain modulation among triathletes: a possible explanation for their exceptional capabilities. Pain, 154(11), 2317-2323.

Gilliam, W. P., Craner, J. R., Morrison, E. J., \& Sperry, J. A. (2017). The mediating effects of the different dimensions of pain catastrophizing on outcomes in an interdisciplinary pain rehabilitation program. The Clinical journal of pain, 33(5), 443-451.

Hu, L.-t., \& Bentler, P. M. (1998). Fit indices in covariance structure modeling: Sensitivity to underparameterized model misspecification. Psychological methods, 3(4), 424.

Hwang, Choi, \& Kwon. (2019). Verification of the structural relationship model of college athletes' perfectionism, anxiety, and aggression in contact and non-contact sports. Korean Journal of Sport Science, 30(1), 160-177.

Jang \& Kang. (2019). The Sources of Stress and Coping Strategies in Pro Baseball Players. Journal of the Korean society for Wellness. 14(2), 335-345.

Jee. (2002). The changes of pain degree, range of motion, and musculo-articulation functions in athletes with isolated posterior cruciate ligament injury. Korean Journal of Physical Education, 41(1), 501-515.

Jones, M. D., Booth, J., Taylor, J. L., \& Barry, B. K. (2014).
Aerobic training increases pain tolerance in healthy individuals. Medicine \& Science in Sports \& Exercise, 46(8), 1640-1647.

Lee \& Kim. (2004). The effect of lumbar extension torque and low back pain on lumbar reinforcement exercise. Korean Journal of Sports Science, 13(1), 633-643.

Marsh, H. W., Hau, K.-T., \& Wen, Z. (2004). In search of golden rules: Comment on hypothesis-testing approaches to setting cutoff values for fit indexes and dangers in overgeneralizing $\mathrm{Hu}$ and Bentler's (1999) findings. Structural equation modeling, 11(3), 320-341.

McHugh, R. K., Kneeland, E. T., Edwards, R. R., Jamison, R., \& Weiss, R. D. (2020). Pain catastrophizing and distress intolerance: prediction of pain and emotional stress reactivity. Journal of behavioral medicine, 43(4), 623-629.

McNeil, D. W., \& Rainwater, A. J. (1998). Development of the fear of pain questionnaire-III. Journal of behavioral medicine, 21(4), 389-410.

Meyers, M. C., Bourgeois, A. E., Stewart, S., \& LeUnes, A. (1992). Predicting pain response in athletes: Development and assessment of the Sports Inventory for Pain. Journal of Sport and Exercise Psychology, 14(3), 249-261.

Meyers, M. C., Bourgeois, A. E., \& LeUnes, A. (2001). Pain coping response of collegiate athletes involved in high contact, high injury-potential sport. International Journal of Sport Psychology, 32(1), 29-42.

Meyer, K., Sprott, H., \& Mannion, A. F. (2008). Cross-cultural adaptation, reliability, and validity of the German version of the Pain Catastrophizing Scale. Journal of psychosomatic research, 64(5), 469-478.

Oh. (2020). The Effects of Core Stabilization Exercise on Blood Lactic Acid and Physical Stress in Musculoskeletal Pain Athletes. The Korean Journal of Growth and Development, 28(4), 531-535.

O'leary, T. J., Collett, J., Howells, K., \& Morris, M. G. (2017). High but not moderate-intensity endurance training increases pain tolerance: a randomised trial. European journal of applied physiology, 117(11), 2201-2210.

Olmedilla Zafra, A., Ortega Toro, E., \& Cano, L. (2013). Validation of the Pain Catastrophizing Scale in Spanish athletes. Cuadernos de Psicología del Deporte, 13(1), 83-93.

Park, Kim, \& Nho. (2008). Vastus medialis oblique and vastus 
lateralis electromyographic activities during closed kinetic chain exercises in male athletes with and without patellofemoral pain syndrome. Korean Journal of Sports Science, 17(1), 487-495.

Pen, L. J., \& Fisher, C. A. (1994). Athletes and pain tolerance. Sports medicine, 18(5), 319-329.

Putukian, M. (2016). The psychological response to injury in student athletes: a narrative review with a focus on mental health. British Journal of Sports Medicine, 50(3), 145-148.

Reis, N. A., Kowalski, K. C., Ferguson, L. J., Sabiston, C. M., Sedgwick, W. A., \& Crocker, P. R. (2015). Self-compassion and women athletes' responses to emotionally difficult sport situations: An evaluation of a brief induction. Psychology of Sport and Exercise, 16, 18-25.

Ryan, E. D., \& Kovacic, C. R. (1966). Pain tolerance and athletic participation. Perceptual and Motor Skills, 22(2), 383-390.

Sciascia, A., Waldecker, J., \& Jacobs, C. (2020). Pain Catastrophizing in College Athletes. Journal of sport rehabilitation, 29(2), 168-173.

Silva, J. M. (1983). The perceived legitimacy of rule violating behavior in sport. Journal of Sport and Exercise Psychology, 5(4), 438-448.

Sullivan, M. J., Bishop, S. R., \& Pivik, J. (1995). The pain catastrophizing scale: development and validation. Psychological assessment, 7(4), 524.

Sullivan, M. J., Stanish, W., Waite, H., Sullivan, M., \& Tripp, D. A. (1998). Catastrophizing, pain, and disability in patients with soft-tissue injuries. Pain, 77(3), 253-260.

Taylor, J., \& Taylor, S. (1998). Pain education and management in the rehabilitation from sports injury. The Sport Psychologist, 12(1), 68-88.
Sullivan, M. J., Tripp, D. A., Rodgers, W. M., \& Stanish, W. (2000). Catastrophizing and pain perception in sport participants. Journal of Applied Sport Psychology, 12(2), 151-167.

Tesarz, J., Schuster, A. K., Hartmann, M., Gerhardt, A., \& Eich, W. (2012). Pain perception in athletes compared to normally active controls: a systematic review with meta-analysis. Pain, 153(6), 1253-1262.

Thornton, C., Sheffield, D., \& Baird, A. (2017). A longitudinal exploration of pain tolerance and participation in contact sports. Scandinavian journal of pain, 16, 36-44.

Udry, E., Gould, D., Bridges, D., \& Beck, L. (1997). Down but not out: Athlete responses to season-ending injuries. Journal of Sport and Exercise Psychology, 19(3), 229-248.

Wang, Ahn, \& Kim. (2016). Effect of joint mobilization on improvement of knee pain, isokinetic strength, muscle tone, muscle stiffness in an elite volleyball player with knee injury. The Korea Academia-Industrial cooperation Society, 17(7), 326-333.

Widaman, K. F., \& Thompson, J. S. (2003). On specifying the null model for incremental fit indices in structural equation modeling. Psychological methods, 8(1), 16.

Williams, J. M., \& Andersen, M. B. (1998). Psychosocial antecedents of sport injury: Review and critique of the stress and injury model. Journal of applied sport psychology, 10(1), 5-25.

Ximing Xu, M., Xianzhao Wei, M., Fei Wang, M., Jie Liu, M., \& Hui Chen, M. (2015). Validation of a simplified Chinese version of the pain catastrophizing scale and an exploration of the factors predicting catastrophizing in pain clinic patients. Pain Physician, 18, E1059-E1072. 


\title{
한국형 스포츠 통증 파국화 척도의 타당성 검증
}

\author{
박인천 \\ 서울과학기술대학교 스포츠과학과 연구조교수
}

[목적] 운동선수들은 통증으로 인해 신체적, 심리적으로 부정적인 영향을 받고 있어 이에 대한 관심과 연구 가 증가하고 있다. 본 연구는 임상현장에서 개발되어 운동선수들에게도 널리 이용되고 있는 통증 파국화 척도 의 타당성을 확인하고, 인식된 스트레스 수준과 통증 두려움과의 관계를 검정하였다. [방법] 무력화(6문항), 반추(4문항), 확대(3문항) 3 요인 13문항으로 구성된 원척도를 검증된 번안과정에 기초하여 번안하였으며 대 학교, 실업팀, 국가대표를 포함하여 현재 운동선수로 활동 중인 206명의 선수를 대상으로 설문을 진행하였다. 수집된 자료의 타당성 검증을 위해 신뢰도 분석, 확인적 요인분석, 상관분석과 회귀분석을 실시하였다. [결과] 첫째, 확인적 요인분석 결과, 요인부하량이 현저히 떨어지는 1 문항을 제거하였을 때 요구되는 모형의 적합도 에 부합하였으며, 각 요인에 대한 신뢰도 또한 타당한 것으로 확인되었다. 둘째, 통증 파국화 하위요인과 인식 된 스트레스 수준 그리고 심각한 통증에 대한 두려움은 정적 상관을 나타내어 이론적 근거를 뒷받침 하는 것으 로 나타났다. 스포츠 통증 파국화 척도의 개념타당도와 예측타당도 역시 타당한 것으로 검증되었다. 마지막으 로 접촉 종목 선수들에 비해 비접촉 종목 선수들이 통증에 대해 더 민감하게 반응하는 것으로 확인되었다. [결론] 본 연구의 결과를 바탕으로 한국형 스포츠 통증 파국화 척도는 우리나라 운동선수들의 주관적 통증 강도를 측정하는데 활용될 수 있을 것으로 판단된다. 또한, 선수들의 부상 후 재활과정을 평가하는데 유용한 정보를 제공할 수 있을 것으로 판단되며, 이러한 정보를 기반으로 통증 관리 중재 프로그램을 개발하는데 있어 구체적인 목표를 설정할 수 있을 것으로 기대된다.

주요어: 통증 파국화, 통증 두려움, 스트레스, 타당도, 운동선수 


\section{Appendix A.}

\section{한국형 통증 파국화 척도}

이 설문지는 자신이 통증을 느낄 때의 사고와 감정을 0 (전혀 그렇지 않다)에서 4(항상 그렇다)까지 5점 척도를 이 용하여 파국적 사고의 정도를 평가는 척도입니다. 설문문항에 정답은 존재하지 않습니다. 본인이 느끼는 감정을 솔직 하게 선택에 주세요.

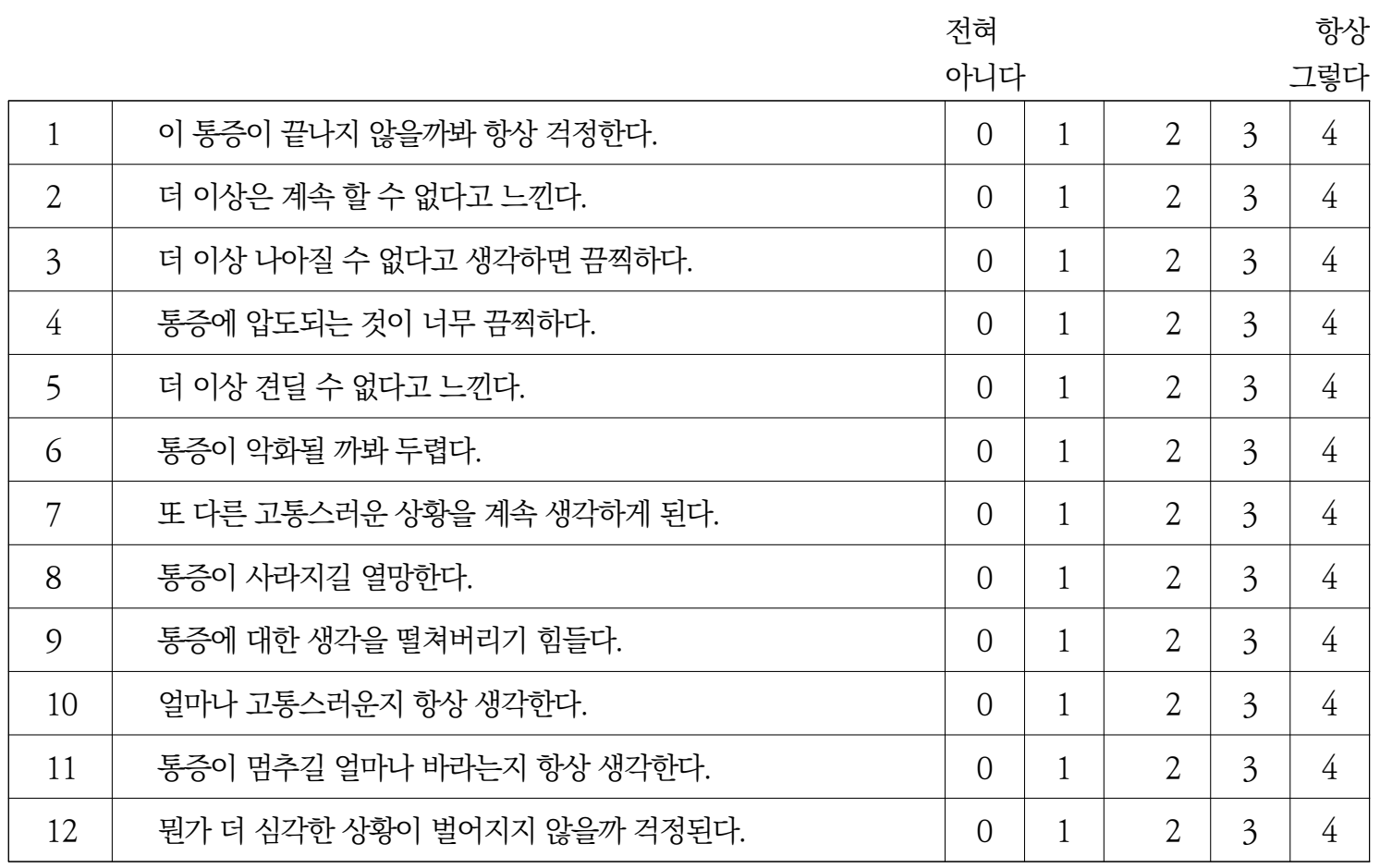

